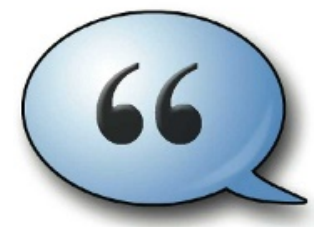

HAVE YOUR SAY

Comment on any of our news stories, online. www.nature.com/news

\title{
Genetics bill cruises through Senate
}

The unanimous vote last week by the US Senate to outlaw discrimination against people on the basis of their genetic information is being celebrated by civilrights groups, which have long campaigned for the safeguards. Personal-genomics companies are also cracking open the champagne - they have a lot to gain from the bill becoming law.

Once enacted, the Genetic Information Nondiscrimination Act (GINA) will forbid employers and health insurers from using people's genetic information against them in decisions on hiring, firing, promotion and insurance coverage and pricing. The House of Representatives should pass the legislation this week, after which it is expected to be signed into law by President George W. Bush.

"This will help the notion of personalized medicine move forward more quickly," says Linda Avey, co-founder of 23andMe, a personal-genetics company in Mountain View, California, that is trail-blazing a highly visible, and controversial, direct-toconsumer market. Avey says her employees erupted in cheers and applause when the bill's passage was announced at a staff meeting the next day. "We were very happy."

The bill is also likely to help other companies that trumpet the virtues of consumers' access to their own genetic data in a way that presumes it won't explode in their hands. "The customers of these new personal-genomics companies are able to download their genomes and share them electronically with others," notes Kathy
Hudson, director of the Genetics and Public Policy Center at Johns Hopkins University in Washington DC. "Until the passage of GINA, the sharing of that information actually put them at risk."

The bill bans US employers from collecting genetic information from their employees, and ensures that insurers can't request or require people to take genetic tests. Sanctions include government fines and lawsuits in federal courts. The House passed a similar bill a year ago, by 420 to 3 . It was then sent to the Senate, where it was stalled by objections from Senator Thomas Coburn (Republican, Oklahoma).

The last of those objections was resolved last month by the insertion of wording preventing companies that insure their own employees from being punished twice under the law: once as an employer, and once as an insurer. But the new language also prevents an employee from suing their employer under the act if both the employer and the insurer are culpable in the same situation.

The wording is ambiguous enough, however, that it "will almost assuredly lead to litigation once it's passed into law", says Jeremy Gruber, the legal counsel for the National Workrights Institute, an employee advocacy group based in Princeton, New Jersey. It will therefore be the courts, he says, that "will clarify which situations might be objectionable enough" for an employer to be sued even if an insurance issue is involved.

The United States is not the first to implement such a law - countries including
Austria and France have laws forbidding genetic discrimination - but it has by far the largest private-insurance market.

The bill took months to get through the Senate and it still has its detractors. The Chamber of Commerce fought the bill on Capitol Hill, claiming that it would burden businesses with paperwork and expense, in part because it doesn't pre-empt a patchwork of existing state laws. "The bill also includes excessive damage provisions that will invite frivolous litigation," the Chamber continues to complain on its website.

But the bill's supporters argue that, rather than burdening the US employers who largely pay for that insurance, it will help them by easing health-care costs. "If we provide these protections, individuals will have the incentive to increasingly avail themselves of medical knowledge," says Senator Olympia Snowe (Republican, Maine), the leading sponsor of the Senate bill. "They may be able to take action as a result, preventing disease or premature death and also reducing the burden of high health-care costs."

For researchers, the law may prove a boon. The next generation of studies to identify gene culprits associated with complex diseases will involve tens of thousands of willing participants as cases and controls. "The success of those kinds of studies, I think, was significantly threatened by people's fears about genetic discrimination," says Hudson.

Meredith Wadman

\section{SNAPSHOT Rodent round-up}

Zoologists have had the Pied Piper's knack of finding rodents this week. This greater white-toothed shrew (Crocidura russula) was discovered in Ireland after biologists were alerted to owl pellets containing large shrew skulls. The large rodent - well, larger than its native Irish cousins such as the pygmy shrew - probably arrived on the island as a stowaway on a ship from North Africa or continental Europe, where it is usually found. Several have now been found in Tipperary and Limerick.

Also reported this week, was the extraordinary find by biologists exploring the mossy mountain forests of Luzon island in the Philippines: a dwarf cloud rat. The species had not been seen since its 1896 discovery and naming by a British biologist. Sadly the reddish-brown rat was dead when spotted high in the canopy of Mount Pulag, the country's second-highest peak. "The cloud rats are one of the most spectacular cases of adaptive radiation by mammals anywhere in the world," says co-discoverer Lawrence Heaney of the Field Museum in Chicago, Illinois.

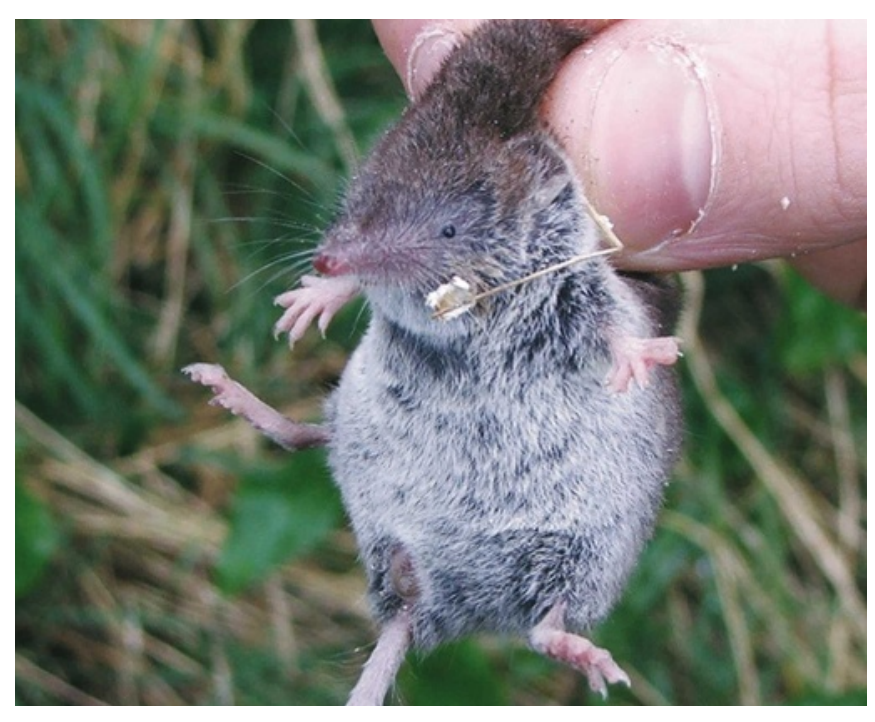

